\title{
Improved grain yield of cowpea (Vigna unguiculata) under water deficit after inoculation with Bradyrhizobium elkanii and Rhizophagus irregularis
}

\author{
Rui S. Oliveira ${ }^{\mathrm{A}, \mathrm{B}, \mathrm{H}}$, Patrícia Carvalho ${ }^{\mathrm{B}}$, Guilhermina Marques ${ }^{\mathrm{C}}$, Luís Ferreira ${ }^{\mathrm{D}}$, Sandra Pereira ${ }^{\mathrm{C}}$, \\ Mafalda Nunes ${ }^{\mathrm{B}}$, Inês Rocha ${ }^{\mathrm{A}}$, Ying Ma ${ }^{\mathrm{A}}$, Maria F. Carvalho ${ }^{\mathrm{E}}$, Miroslav Vosátka ${ }^{\mathrm{F}} \mathrm{G}$, and Helena \\ Freitas $^{\mathrm{A}}$ \\ ${ }^{A}$ Centre for Functional Ecology, Department of Life Sciences, University of Coimbra, Calçada Martim de Freitas, \\ 3000-456 Coimbra, Portugal. \\ ${ }^{B}$ Department of Environmental Health, Research Centre on Health and Environment, School of Allied Health \\ Sciences, Polytechnic Institute of Porto, Rua Dr António Bernardino de Almeida, 400, 4200-072, Porto, Portugal. \\ ${ }^{C}$ University of Trás-os-Montes e Alto Douro, Centre for the Research and Technology of Agro-Environmental and \\ Biological Sciences (UTAD-CITAB), Quinta de Prados, 5000-801 Vila Real, Portugal. \\ ${ }^{D}$ Animal and Veterinary Research Centre (CECAV), University of Trás-os-Montes and Alto Douro (UTAD), \\ Quinta de Prados, 5000-801 Vila Real, Portugal. \\ ${ }^{E}$ CIIMAR - Interdisciplinary Centre of Marine and Environmental Research, University of Porto, Terminal de \\ Cruzeiros do Porto de Leixões, Avenuenida General Norton de Matos, 4450-208 Matosinhos, Portugal. \\ F Institute of Botany, Academy of Sciences of the Czech Republic, Zámek 1, 25243 Pru honice, Czech Republic. \\ ${ }^{\mathrm{G}}$ Department of Experimental Plant Biology, Charles University, Faculty of Science, Viničná 5, Praha 2, \\ Czech Republic. \\ ${ }^{H}$ Corresponding author. Email: rsoliveira@uc.pt
}

\begin{abstract}
Cowpea (Vigna unguiculata (L.) Walp.), a plant broadly cultivated for human consumption and animal feed, is among the most nutritious grain legumes. Most of the areas where cowpea is grown are drought-prone, and there is a need to address this issue, with water scarcity becoming a major concern in agriculture. Cowpea is known to form mutualistic associations with nitrogen-fixing (NF) bacteria and arbuscular mycorrhizal (AM) fungi. These beneficial soil microorganisms have the capacity to benefit plants by reducing the effects of environmental stresses, including drought. Our aim was to study the effect of inoculation with Bradyrhizobium elkanii and Rhizophagus irregularis on the growth and grain yield of cowpea under water-deficit conditions. Under moderate water deficit, grain yield was increased by $63 \%, 55 \%$ and $84 \%$ in plants inoculated with B. elkanii, $R$. irregularis and B. elkanii $+R$. irregularis, respectively. Under severe water deficit, inoculation with $B$. elkanii and B. elkanii $+R$. irregularis resulted in grain-yield enhancement of $45 \%$ and $42 \%$, respectively. The use of cowpea inoculated with NF bacteria and AM fungi has great potential for sustainable agricultural production under drought conditions.
\end{abstract}

Additional keywords: plant-microbe interactions, pulses, rhizobia, sustainable agriculture, tripartite symbiosis, water stress.

\section{Introduction}

Cowpea (Vigna unguiculata (L.) Walp.) is highly versatile and one of the most important grain legume crops. It is widely cultivated, especially in the semi-arid tropical regions, where it provides a cheap source of rich vegetable protein for human consumption (Ehlers and Hall 1997; Timko and Singh 2008). Valued as food, forage and a green manure crop in many parts of the world, cowpea contributes to the sustainability of cropping systems and improves soil fertility through nitrogen $(\mathrm{N})$ fixation.
Cowpea can grow successfully with few economic inputs in low-fertility and marginal soils, and it can be used to increase the yields of cereal crops when grown in rotation (Fery 2002; Bell et al. 2017). In addition to being drought-tolerant, cowpea has high yield potential. Worldwide, the cultivated area of cowpea is estimated to have increased from 2.4 Mha in 1961 to $>12.5$ Mha in 2014 , with an economic value of US $\$ 1.5$ billion (FAOSTAT 2017). Although exact statistics are not available, Singh et al. (2002) estimated an annual global production of 
cowpea of 4.5 Mt. The region encompassing West and Central Africa contributes $\sim 70 \%$ of world cowpea production. Other major production areas are Asia, Central and South America, and southern and south-eastern Europe (Singh et al. 2002). Farmers from Africa and Asia not only grow cowpea for dry seed, but also utilise the leaves and fruits for human consumption and animal feed. In high-income countries, cowpea is becoming regarded as an alternative to soybean as consumers seek more traditional foods with health benefits (Rangel et al. 2004; Timko and Singh 2008). Cowpea seeds are rich in proteins and carbohydrates and contain substantial amounts of lysine, tryptophan, minerals and vitamins (folic acid and vitamin B) (Nielsen et al. 1993; Timko and Singh 2008).

Most areas where cowpea is grown are semi-arid and often experience severe to moderate droughts (Hall 2012). Global water scarcity is increasing pressure to produce more food with less water; therefore, drought-tolerant crops such as cowpea are of great interest for sustainable agriculture. Its long taproot and resistance mechanisms such as closing the stomata when soil-water supply is insufficient and turning the leaves upwards to protect them from excessive temperatures give cowpea a unique ability to survive extreme droughts that would kill most other crop plants (Schakel and Hall 1979; Hall 2012; Halilou et al. 2015). For example, under irrigated and optimal conditions, production was up to $4000 \mathrm{~kg} \mathrm{ha}^{-1}$ in Senegal (Hall 2012). The growth performance of cowpea can be significantly improved through associations with nitrogen-fixing (NF) rhizobia (Figueiredo et al. 1998, 1999). Bradyrhizobium elkanii, B. yuanmingense and B. japonicum are among the main rhizobial species associated with cowpea (Zhang et al. 2008). However, drought can reduce significantly the biological $\mathrm{N}_{2}$ fixation by associated rhizobia and cause plants to rely more on available inorganic N (Elowad and Hall 1987).

Like most land plants, cowpea also associates with arbuscular mycorrhizal (AM) fungi. Work on the tripartite symbiosis of legume-rhizobia-AM fungi has showed that AM fungi can improve nodulation and biological $\mathrm{N}_{2}$ fixation within the nodule (Wilson et al. 2012; Ossler et al. 2015). Enhanced performance of legumes by AM fungal symbiosis is the result of promotion of key processes benefiting plant vigour, biomass production and fitness (Chalk et al. 2006). AM fungi can benefit plants by reducing the effects of environmental stresses (Oliveira et al. 2005a, 2010). They have the capacity to improve uptake of nutrients (Oliveira et al. 2006, 2016a, 2016b) and to increase drought tolerance (Augé et al. 2015), which may contribute to improved crop yield under adverse environmental conditions.

We aimed at assessing the effects of single and dual inoculation with an NF bacterium and an AM fungus on the biomass, leaf chlorophyll concentration, crude protein content and grain yield of cowpea under water-deficit conditions.

\section{Materials and methods \\ Biological material and soil}

The bacterial isolate used in this work, Bradyrhizobium elkanii FF24-2, was isolated from a surface-sterilised nodule present in the roots of a cowpea plant in a field in Vila Real, Portugal. This bacterial strain was chosen for its fast-growing capacity and its ability to nodulate cowpea successfully (G. Marques, pers. comm.). The bacterium was isolated in yeast mannitol agar (YMA) medium containing $\left(\mathrm{g} \mathrm{L}^{-1}\right)$ : yeast extract, 1; mannitol, $10 ; \mathrm{K}_{2} \mathrm{HPO}_{4}, 0.5 ; \mathrm{MgSO}_{4} .7 \mathrm{H}_{2} \mathrm{O}, 0.2 ; \mathrm{NaCl}, 0.1$; agar, 15. First, it was streaked in YMA medium supplemented with $0.025 \mathrm{~g} \mathrm{~L}^{-1}$ of Congo red. A single colony was picked and streaked in the same medium supplemented with $0.1 \mathrm{~g} \mathrm{~L}^{-1}$ of bromothymol blue (BTB) (Somasegaran and Hoben 1985). The isolate was purified by repeated streaking in YMA medium supplemented with BTB, and then, for molecular identification, the DNA was extracted manually according to Sikora et al. (2002). The nearly full-length 16S rDNA gene (Weisburg et al. 1991) was amplified, and in order to identify the bacterium at the species level, this analysis was complemented with nodC (Laguerre et al. 2001) genes. Based on the alignment of the obtained sequences of $16 \mathrm{~S}$ rDNA and partial nodC gene, a $100 \%$ pair-wise identity was observed with $B$. elkanii. The GenBank accession numbers of the publically available sequences showing the best match with the obtained sequences for $16 \mathrm{~S}$ rDNA and partial nodC gene were KX396582 and FJ418725, respectively. The bacterial isolate B. elkanii FF24-2 was grown in yeast mannitol broth (YMB) (Sigma-Aldrich, St. Louis, MO, USA) for 3 days at $28^{\circ} \mathrm{C}$ and $0.5 g$. The culture was then centrifuged at $4930 \mathrm{~g}$ for $10 \mathrm{~min}$ and the pellet was washed with saline solution $(0.85 \% \mathrm{NaCl})$. The pellet was resuspended in saline solution and the colony forming unit adjusted to $10^{9} \mathrm{~mL}^{-1}$.

The AM fungal isolate Rhizophagus irregularis BEG140 was grown for 8 months in a multi-spore pot culture containing a $1: 1$ (v/v) mixture of zeolite and expanded clay with Zea mays L. as the host plant (Symbiom Ltd, Sázava, Czech Republic). This AM fungal isolate was chosen because of root-colonisation capacity shown in previous experiments (Oliveira et al. 2016b). The inoculum had 400 AM fungal propagules $\mathrm{g}^{-1}$, estimated by the most probable number method (Porter 1979).

The seeds used in this study were from cowpea cv. Fradel obtained from the collection of the University of Trás-os-Montes e Alto Douro, Vila Real, Portugal. Soil was collected from the uppermost $10-\mathrm{cm}$ layer of an organic farm in northern Portugal, sieved through a 4-mm mesh and autoclaved twice $\left(121^{\circ} \mathrm{C}\right.$ for $\left.25 \mathrm{~min}\right)$ on consecutive days. This was a sandy soil with $\mathrm{pH}(1: 2.5 \mathrm{w} / \mathrm{v}$ water $) 6.5$, electrical conductivity $0.1 \mathrm{dS} \mathrm{m}^{-1}, 1.2 \%$ organic matter, total $\mathrm{N} 3.8 \mathrm{~g} \mathrm{~kg}^{-1}$, extractable (Egner-Riehm) phosphorus $48.8 \mathrm{mg} \mathrm{kg}^{-1}$, potassium $4.3 \mathrm{~g} \mathrm{~kg}^{-1}$, calcium $1.6 \mathrm{~g} \mathrm{~kg}^{-1}$, magnesium $66 \mathrm{mg} \mathrm{kg}^{-1}$ and sodium $147 \mathrm{mg} \mathrm{kg}^{-1}$.

\section{Experimental treatments and setup}

Experimental units (1-L pots filled with soil) were arranged in a fully randomised manner using a $2 \times 2 \times 3$ factorial design. The first factor was bacterial inoculation (non-inoculated plants and plants inoculated with $B$. elkanii), the second factor was fungal inoculation (non-inoculated plants and plants inoculated with $R$. irregularis), and the third factor was water deficit (no water deficit, moderate water deficit and severe water deficit). Thus, for each water regime there were four treatments: non-inoculated plants, plants inoculated with $B$. elkanii, plants inoculated with $R$. irregularis and dually inoculated plants. Each treatment combination was replicated 10 times. Seeds of cowpea were surface-sterilised with $0.5 \%(\mathrm{v} / \mathrm{v})$ sodium hypochlorite for $20 \mathrm{~min}$, placed on moist paper towels and germinated at $20^{\circ} \mathrm{C}$ in the dark. After germination, seedlings of similar size were 
transplanted, one plant into each pot. A nitrocellulose membrane filter (diameter $24 \mathrm{~mm}$ and pore size $0.4 \mu \mathrm{m}$ ) (Pragopore; Pragochema Ltd, Prague) was inserted vertically in each pot for future measurements of extraradical mycelium (ERM) length (Baláz and Vosátka 2001). At transplanting, each pot from the bacterial treatments received $4 \mathrm{~mL}$ bacterial suspension (described above). Every pot from the non-bacterial treatments received $4 \mathrm{~mL}$ autoclaved bacterial suspension. Each pot from the mycorrhizal treatments received $10 \mathrm{~g}$ inoculum consisting of colonised root fragments, hyphae and spores in the mixture of zeolite and expanded clay, placed $2 \mathrm{~cm}$ below the root system. Every pot from the non-mycorrhizal treatments received $10 \mathrm{~g}$ inoculum autoclaved twice $\left(121^{\circ} \mathrm{C}\right.$ for $\left.25 \mathrm{~min}\right)$ on consecutive days. In order to eliminate differences in bacterial populations introduced with the AM fungal inoculum, a 5-mL filtrate of AM fungal inoculum was added to all pots from the non-mycorrhizal treatments (Koide and Li 1989). The filtrate was prepared as described in Oliveira et al. (2010). Field capacity of the soil in the pots was determined (Grewal et al. 1990), and during the first 4 weeks, soil moisture in all pots was kept at $75 \%$ of field capacity by weighing the pots every 2 days and watering accordingly with deionised water. Soil moisture was kept at $75 \%, 50 \%$ and $25 \%$ of field capacity by weighing the pots for the treatments with no water deficit, moderate water deficit and severe water deficit, respectively. Plants were grown in a greenhouse under natural light with an average photoperiod of $12 \mathrm{~h}$. Temperature and relative humidity ranges were $12-42^{\circ} \mathrm{C}$ and $55-85 \%$, respectively. Pots of different treatments were periodically rotated to different bench positions and rerandomised to minimise differences due to their location in the greenhouse.

\section{Measurements and analyses}

After a growth period of 3 months, grains were harvested and the number of grains per plant, fresh weight of grains per plant and fresh weight per grain were determined. Grain samples were dried at $80^{\circ} \mathrm{C}$ for $48 \mathrm{~h}$ and analysed for total Kjeldahl $\mathrm{N}$ following the methods of the Association of Official Analytical Chemists (2006). Crude protein was calculated as $\mathrm{N} \times 6.25$ (FAO 2003). A fresh subsample $(0.02 \mathrm{~g})$ was cut from the second mature leaf from the plant apex and the concentrations of chlorophyll $\mathrm{a}+\mathrm{b}$ determined after extraction with N,N-dimethylformamide according to Wellburn (1994). Plants were removed from the pots, and the root system was separated from the shoot and gently washed to remove adhered soil. Number of root nodules was counted. A fresh subsample $(0.2 \mathrm{~g})$ of roots was collected to assess AM colonisation (described below). The remaining root system was weighed and dried at $80^{\circ} \mathrm{C}$ for $48 \mathrm{~h}$ together with the shoot. The dried root system and shoot were then re-weighed. The dry root mass of the subsample was calculated by multiplying its fresh mass by the dry : fresh mass ratio of the root system. The sum of the dry mass of the root subsample, the dry mass of the root system and the dry mass of the shoot gave the total dry weight per plant. The subsample of fresh roots was cut into 1-cm pieces and stained with trypan blue, using a modified (Phillips and Hayman 1970) protocol (Oliveira et al. 2005b). Percentage root-length colonised (RLC) by AM fungi was assessed for each plant species by using the grid-line intersect method (Giovannetti and Mosse 1980) under a stereomicroscope (Olympus SZ61; Olympus, Tokyo).
The ERM length was determined by using the inserted membrane technique (Baláz and Vosátka 2001) followed by the grid-line intersect method under a compound microscope (Leica DM 750: Leica, Wetzlar, Germany), using an ocular grid at $200 \times$ magnification (Brundrett et al. 1994). Background lengths of mycelium found in non-mycorrhizal treatments were subtracted from the values obtained in the corresponding mycorrhizal treatments and the ERM length was expressed in $\mathrm{cm}$ hyphae per $\mathrm{cm}^{2}$ inserted membrane filter.

\section{Statistical analyses}

Normality and homogeneity of variances were confirmed and data analysed by using three-way analysis of variance (ANOVA) for each dependent variable (plant parameters) vs. independent variables (bacterial inoculation, fungal inoculation and water deficit). When a significant $F$-value was obtained $(P<0.05)$, treatment means were compared by Duncan's multiple range test. Microbial parameter data were analysed by two-way ANOVA without including the respective non-inoculated control treatments. All statistical analyses were performed with the SPSS 23.0.0.0 software package (IBM, Armonk, NY, USA).

\section{Results}

Cowpea growth

Inoculation with $R$. irregularis significantly increased root, shoot and total plant dry weight of cowpea without water deficit (Fig. $1 a-c$ ). Overall, under moderate and severe water deficit there was no effect of microbial inoculation (either singly or dually) on plant biomass. However, leaf chlorophyll $\mathrm{a}+\mathrm{b}$ concentration was significantly increased under moderate water deficit with bacterial inoculation and under severe after deficit with dual inoculation (Fig. 1d). Water deficit significantly influenced plant biomass and leaf chlorophyll $\mathrm{a}+\mathrm{b}$ concentration, whereas inoculation with $B$. elkanii had a significant effect only on leaf chlorophyll $\mathrm{a}+\mathrm{b}$ concentration (Table 1 ).

Microbial inoculation did not cause any significant reduction in root, shoot and total plant dry weight or in leaf chlorophyll $\mathrm{a}+\mathrm{b}$ concentration compared with the respective non-inoculated controls, regardless of the water regime (Fig. 1).

\section{Cowpea grain yield}

Bacterial inoculation and water deficit significantly influenced all grain-yield-related parameters (number of grains per plant, fresh weight of grains per plant, fresh weight per grain), whereas fungal inoculation had no significant effect (Table 2).

Without water deficit, inoculation with $B$. elkanii+ $R$. irregularis significantly increased the number of cowpea grains produced per plant (Fig. 2a). Under moderate water deficit, inoculation with $B$. elkanii alone and with $B$. elkanii + $R$. irregularis resulted in a significantly higher number of grains per plant. However, when severe water deficit was imposed, there was no improvement in the number of grains per plant in any inoculation treatment.

Bacterial inoculation and dual inoculation led to a significant increase in the fresh weight of grains produced per plant under both moderate and severe water deficit, whereas fungal inoculation produced a significant improvement only under moderate water deficit (Fig. 2b). Without water deficit, dual 

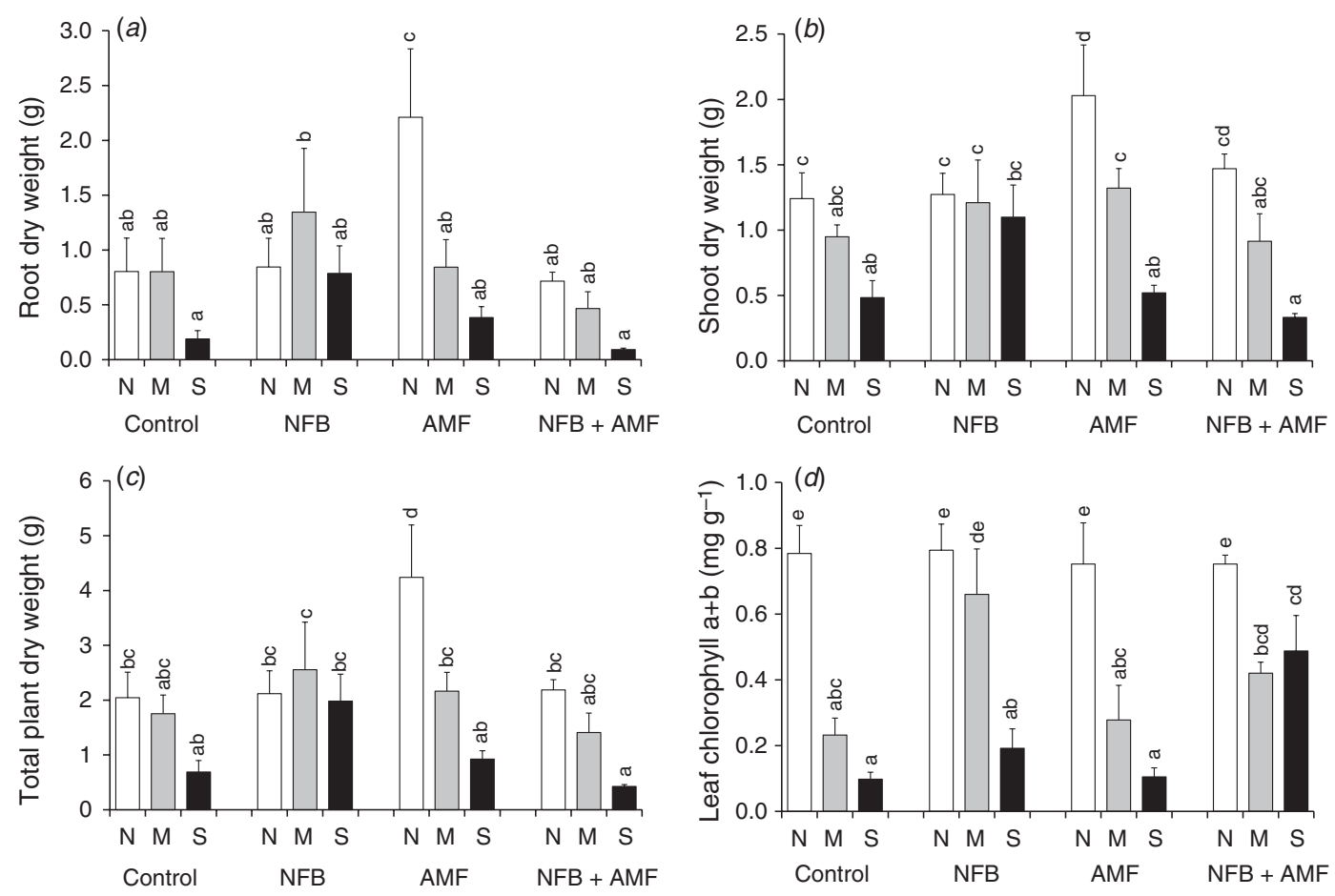

Fig. 1. (a) Root dry weight, $(b)$ shoot dry weight, $(c)$ total plant dry weight, and $(d)$ leaf chlorophyll a + b concentration of cowpea grown under different water regimes and inoculated with Bradyrhizobium elkanii and Rhizophagus irregularis. Values are means \pm 1 s.e. Means with the same letter are not significantly different according to Duncan's multiple range test at $P=0.05$. NFB, Nitrogen-fixing bacterium; AMF, arbuscular mycorrhizal fungus; $N$, no water deficit; $M$, moderate water deficit; $S$, severe water deficit.

Table 1. Three-way ANOVA $F$-values and significances of cowpea biomass and leaf chlorophyll a $+b$ concentration according to bacterial inoculation, fungal inoculation and water-deficit factors ${ }^{*} P<0.05 ;{ }^{*} P<0.01 ; * * P<0.001 ;$ n.s., not significant $(P>0.05)$

\begin{tabular}{llccc}
\hline & $\begin{array}{c}\text { Root dry } \\
\text { weight }\end{array}$ & $\begin{array}{c}\text { Shoot dry } \\
\text { weight }\end{array}$ & $\begin{array}{c}\text { Total plant dry } \\
\text { weight }\end{array}$ & $\begin{array}{c}\text { Leaf chlorophyll a b } \\
\text { concentration }\end{array}$ \\
\hline Bacterial inoculation (B) & 0.8 n.s. & 0.1 n.s. & 0.5 n.s. & $13.4^{* * * *}$ \\
Fungal inoculation (F) & 0.003 n.s. & 0.2 n.s. & 0.01 n.s. & 0.01 n.s. \\
Water deficit (W) & $6.4^{* *}$ & $19.9^{* * *}$ & $11.5^{* * *}$ & $45.4^{* * *}$ \\
$\mathrm{~B} \times \mathrm{F}$ & $9.8^{* *}$ & $8.8^{* *}$ & $10.8^{* *}$ & $0.001 \mathrm{n} . \mathrm{s}$. \\
$\mathrm{B} \times \mathrm{W}$ & $2.5 \mathrm{n} . \mathrm{s}$. & $1.4 \mathrm{n} . \mathrm{s}$. & $2.2 \mathrm{n} . \mathrm{s}$. & $3.3^{*}$ \\
$\mathrm{~F} \times \mathrm{W}$ & $3.4^{*}$ & $4.6^{*}$ & 4.0 & $2.4 \mathrm{n} . \mathrm{s}$. \\
$\mathrm{B} \times \mathrm{F} \times \mathrm{W}$ & $0.4 \mathrm{n} . \mathrm{s}$. & $0.1 \mathrm{n} . \mathrm{s}$. & $0.1 \mathrm{n} . \mathrm{s}$. & $3.0 \mathrm{n} . \mathrm{s}$. \\
\hline
\end{tabular}

Table 2. Three-way ANOVA $F$-values and significance of number, weight and crude protein content of cowpea grains according to bacterial inoculation, fungal inoculation and water-deficit factors $* P<0.05 ; * * P<0.01 ; * * *<0.001 ;$ n.s., not significant $(P>0.05)$

\begin{tabular}{|c|c|c|c|c|}
\hline & $\begin{array}{l}\text { No. of grains } \\
\text { per plant }\end{array}$ & $\begin{array}{c}\text { Fresh weight } \\
\text { of grains } \\
\text { per plant }\end{array}$ & $\begin{array}{l}\text { Fresh weight } \\
\text { per grain }\end{array}$ & $\begin{array}{l}\text { Crude protein } \\
\text { of grains }\end{array}$ \\
\hline Bacterial inoculation (B) & $14.3 * * *$ & $50.0 * * *$ & $21.6 * * *$ & $14.9 * * *$ \\
\hline Fungal inoculation $(\mathrm{F})$ & $2.3 \mathrm{n} . \mathrm{s}$ & $1.7 \mathrm{n} . \mathrm{s}$. & $0.1 \mathrm{n} . \mathrm{s}$. & 0.07 n.s. \\
\hline Water deficit (W) & $170.0 * * *$ & $242.3 * * *$ & $4.8^{* *}$ & $2.7 \mathrm{n} . \mathrm{s}$. \\
\hline $\mathrm{B} \times \mathrm{F}$ & $0.4 \mathrm{n} . \mathrm{s}$ & $5.2 *$ & 0.7 n.s. & $0.4 \mathrm{n} . \mathrm{s}$. \\
\hline $\mathrm{B} \times \mathrm{W}$ & $0.1 \mathrm{n} . \mathrm{s}$. & $3.7 *$ & $0.8 \mathrm{n} . \mathrm{s}$. & $0.1 \mathrm{n} . \mathrm{s}$. \\
\hline $\mathrm{F} \times \mathrm{W}$ & $0.3 \mathrm{n} . \mathrm{s}$. & $1.7 \mathrm{n} . \mathrm{s}$. & $1.9 \mathrm{n} . \mathrm{s}$. & $1.2 \mathrm{n} . \mathrm{s}$. \\
\hline $\mathrm{B} \times \mathrm{F} \times \mathrm{W}$ & $5.4^{* *}$ & $12.7 * * *$ & $2.7 \mathrm{n} . \mathrm{s}$. & $0.5 \mathrm{n} . \mathrm{s}$ \\
\hline
\end{tabular}



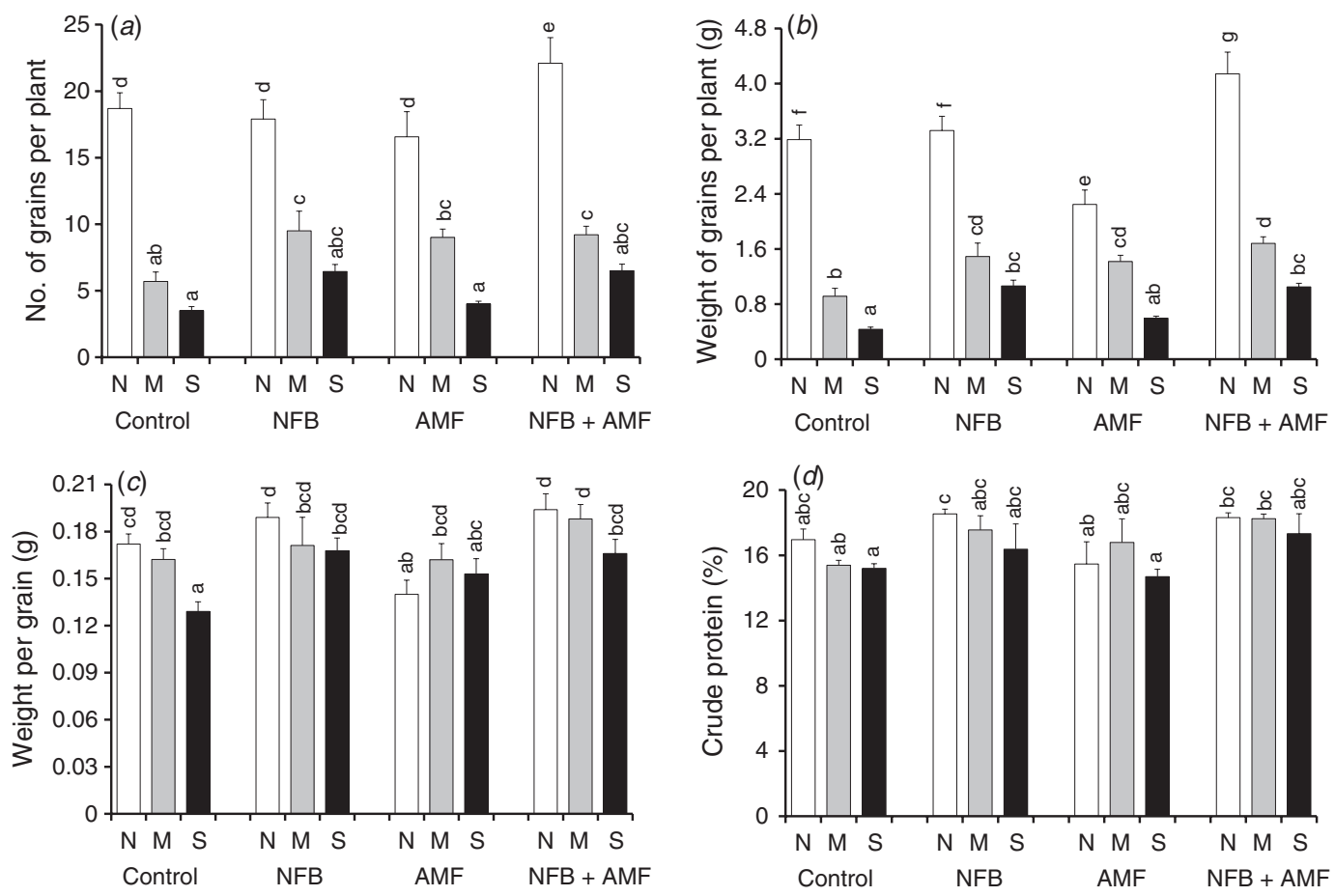

Fig. 2. (a) Number of grains per plant, $(b)$ fresh weight of grains per plant, $(c)$ fresh weight per grain, and $(d)$ crude protein percentage of grains of cowpea grown under different water regimes and inoculated with Bradyrhizobium elkanii and Rhizophagus irregularis. Values are means \pm 1 s.e. Means with the same letter are not significantly different according to Duncan's multiple range test at $P=0.05$. NFB, Nitrogen-fixing bacterium; AMF, arbuscular mycorrhizal fungus; N, no water deficit; $\mathrm{M}$, moderate water deficit; $\mathrm{S}$, severe water deficit.

inoculation significantly increased the weight of grains per cowpea plant.

There was no enhancement of the weight per grain produced by cowpea without water deficit or under moderate water deficit in any microbial inoculation. However, under severe water deficit, plants inoculated with B. elkanii or with B. elkanii + R. irregularis produced heavier grains than the respective non-inoculated control (Fig. 2c).

There were no significant differences in the crude protein content of cowpea grains between non-inoculated controls and inoculated plants, irrespective of inoculation treatment and water regime (Fig. 2d).

\section{Microbial performance}

There were no nodules of B. elkanii and no mycorrhizal colonisation in the roots of non-inoculated cowpea (Table 3). Plants under severe water deficit had a significantly reduced number of root nodules compared with those without water deficit and those under moderate water deficit in both inoculation treatments (B. elkanii and B. elkanii + R. irregularis).

Bacterial inoculation significantly increased mycorrhizal colonisation in moderate and non-deficit water regimes. There was no influence of bacterial inoculation or water deficit on the length of the ERM of $R$. irregularis.

\section{Discussion}

Cowpea is cropped mainly for its grain, but the leaves are also used for human consumption and the dried stalks are valuable as animal feed (Iqbal 2015). Our results showed that inoculation with an AM fungus significantly increased below- and aboveground biomass of cowpea without water deficit. This is in accordance with the work of Omirou et al. (2016) and indicates that AM fungi have the potential to improve the sustainable production of cowpea. However, when water deficit (moderate or severe) was imposed in our study, no benefit of microbial inoculation was observed. No benefit in plant biomass of cowpea inoculated with AM fungi under water stress was also reported by Diallo et al. (2001). Those authors showed that under waterstressed conditions (drought), the root and shoot dry matter of plants inoculated with Glomus mosseae or G. versiforme did not differ significantly from non-inoculated controls. They related this lack of effect to the lack of significant differences in leaf osmotic potential, stomatal conductance and leaf transpiration in mycorrhizal cowpea and suggested that AM fungal inoculation did not affect stomatal closure.

Oliveira et al. (2005a) showed that plants inoculated with an NF bacterium alone or in combination with an AM fungus exhibited significantly higher leaf chlorophyll $\mathrm{a}+\mathrm{b}$ concentration. Similarly, in the present study, the leaf chlorophyll $\mathrm{a}+\mathrm{b}$ concentration was significantly increased under moderate water deficit with bacterial inoculation and under severe water deficit with dual inoculation, indicating that cowpea inoculated with $B$. elkanii or with $B$. elkanii + $R$. irregularis had higher photosynthetic potential. Although this potential did not translate into increased plant biomass, it may have contributed to improve grain yield. 
Table 3. Number of root nodules, arbuscular mycorrhizal fungal (AMF) colonisation and length of extraradical mycelium (ERM) of cowpea inoculated with Bradyrhizobium elkanii and Rhizophagus irregularis under different water regimes

RLC, Root length colonised. Within columns, means ( \pm 1 s.e.) followed by the same letters are not significantly different according to Duncan's multiple range test at $P=0.05$. ${ }^{*} P<0.01 ; * * * P<0.001 ;$ n.s., not significant $(P>0.05)$

\begin{tabular}{|c|c|c|c|c|}
\hline Inoculation & Water deficit & $\begin{array}{c}\text { No. of } \\
\text { nodules }\end{array}$ & $\begin{array}{l}\text { AMF colonisation } \\
(\% \text { RLC })\end{array}$ & $\begin{array}{l}\text { ERM length } \\
\left(\mathrm{cm} \mathrm{cm}^{-2}\right)\end{array}$ \\
\hline \multirow[t]{3}{*}{ Bradyrhizobium elkanii } & None & $61 \pm 3 b$ & 0 & 0 \\
\hline & Moderate & $79 \pm 15 b$ & 0 & 0 \\
\hline & Severe & $20 \pm 2 \mathrm{a}$ & 0 & 0 \\
\hline \multirow[t]{3}{*}{ Rhizophagus irregularis } & None & 0 & $34 \pm 3 a$ & $8 \pm 2$ \\
\hline & Moderate & 0 & $28 \pm 3 a$ & $13 \pm 3$ \\
\hline & Severe & 0 & $30 \pm 4 \mathrm{a}$ & $14 \pm 3$ \\
\hline \multirow[t]{3}{*}{ B. elkanii $+R$. irregularis } & None & $56 \pm 6 b$ & $46 \pm 3 b$ & $19 \pm 12$ \\
\hline & Moderate & $63 \pm 11$ & $45 \pm 6 b$ & $21 \pm 8$ \\
\hline & Severe & $14 \pm 4 \mathrm{a}$ & $29 \pm 4 \mathrm{a}$ & $12 \pm 5$ \\
\hline \multicolumn{5}{|c|}{ Two-way ANOVA $F$-values and significances } \\
\hline \multicolumn{2}{|l|}{ Bacterial inoculation (B) } & & $8.9^{* *}$ & $1.0 \mathrm{n} . \mathrm{s}$. \\
\hline \multicolumn{2}{|l|}{ Fungal inoculation (F) } & $1.1 \mathrm{n} . \mathrm{s}$. & & \\
\hline \multicolumn{2}{|l|}{ Water deficit (W) } & $12.4^{* * *}$ & 3.3n.s. & $0.2 \mathrm{n} . \mathrm{s}$. \\
\hline \multicolumn{2}{|l|}{$\mathrm{B} \times \mathrm{W}$} & & 2.9 n.s. & $0.4 \mathrm{n} . \mathrm{s}$. \\
\hline \multicolumn{2}{|l|}{$\mathrm{F} \times \mathrm{W}$} & 0.2 n.s. & & \\
\hline
\end{tabular}

Under moderate water deficit, grain yield (in terms of both number of seeds produced and total weight of seeds per plant) was significantly higher with microbial inoculation. There was an increase in the number of seeds of $67 \%$ and $61 \%$ in cowpea inoculated with B. elkanii and B. elkanii $+R$. irregularis, respectively; and an increase of $63 \%, 55 \%$ and $84 \%$ in the total weight of seeds per plant inoculated with $B$. elkanii, $R$. irregularis and $B$. elkanii $+R$. irregularis, respectively. Under severe water deficit, inoculation with $B$. elkanii and $B$. elkanii $+R$. irregularis resulted in an enhancement of total weight of seeds per plant of $45 \%$ and $42 \%$, respectively. These results show that NF bacteria and AM fungi can increase grain yield of cowpea under both moderate and severe waterdeficit conditions; however, the benefit of adding NF bacteria and the combination of both microorganisms varies with the level of water deficit. Overall, dual inoculations (NF bacterium + AM fungus) were the treatments in which superior grain yield was achieved. Furthermore, dually inoculated cowpea plants produced heavier seeds under severe water stress compared with the respective non-inoculated control. Ngakou et al. (2008) also reported improved grain yield of cowpea inoculated with $\mathrm{NF}$ bacterium + AM fungus. Microbial inoculation brought no increase in crude protein content of cowpea grains under our experimental conditions. In a meta-analysis with 12 legume species, Kaschuk et al. (2010) found increases in grain protein of $7 \%$ and $14 \%$ in plants inoculated with rhizobia in the field and with AM fungi in pot experiments, respectively. However, cowpea was not included in their study.

Nodulation was not affected by moderate water deficit; nonetheless, there was a significant reduction of nodulation in the severe water-stress treatments. Inoculation with $R$. irregularis was unable to alleviate this reduction. Similarly, Omirou et al. (2016) found no effect of AM fungal inoculation on cowpea nodulation. Water-deficit stress has been shown to reduce nodulation and $\mathrm{N}_{2}$ fixation of different Bradyrhizobium strains in symbiosis with cowpea (Figueiredo et al. 1998, 1999). However, it was demonstrated that the susceptibility to drought is strain-specific.

Mycorrhizal colonisation (\%RLC) of cowpea inoculated with $R$. irregularis varied between $29 \%$ and $46 \%$, which is in accordance with previous studies on interactions between cowpea and AM fungi (Bagayoko et al. 2000; Augé et al. 2001; Omirou et al. 2016). Inoculation with B. elkanii increased root colonisation of $R$. irregularis under all water regimes except severe water deficit. Significantly higher mycorrhizal root colonisation in cowpea inoculated with NF bacteria was previously found in experiments without water stress (Ames et al. 1991; Taiwo et al. 2001). Severe water deficit was detrimental to nodulation of $B$. elkanii and might have reduced its ability to fix $\mathrm{N}_{2}$ (Figueiredo et al. 1998, 1999). The reduced cowpea fitness under severe water deficit and the higher drain on plant photosynthates during the tripartite symbiosis might have contributed to the observed decrease in mycorrhizal colonisation.

Inoculation with $B$. elkanii $+R$. irregularis improved grain yield of cowpea under water deficit. Drought is one of the main challenges in agriculture. Hence, the use of cowpea inoculated with NF bacteria + AM fungi has great potential to tackle problems arising from water scarcity. These beneficial soil microorganisms can be regarded as biotechnological tools for sustainable agriculture in drought scenarios. The study also indicated that the NF bacterial inoculant is potentially resistant to moderate water stress. The AM fungal inoculant shows considerable resistance to moderate and even severe drought stress, and that applies to both the intra- and extraradical phase of the symbiosis. There is the prospect that, in the field, the inoculants might persist over drought periods and maintain mutualistic capacity with the host. Nevertheless, this would have to be tested under field conditions, using different isolates of AM fungi and NF bacteria. 


\section{Acknowledgements}

RS Oliveira, Y Ma and I Rocha acknowledge the support of Fundação para a Ciência e a Tecnologia (FCT) through the research grants SFRH/BPD/ 85008/2012, SFRH/BPD/76028/2011 and SFRH/BD/100484/2014, Fundo Social Europeu (FSE) and Programa Operacional do Capital Humano $(\mathrm{POCH})$. This work was financed by Portuguese national funds through Programa Operacional Competitividade e Internacionalização (POCI), Project 3599-Promover a Produção Científica e Desenvolvimento Tecnológico e a Constituição de Redes Temáticas (3599-PPCDT) and Fundo Europeu de Desenvolvimento Regional (FEDER) under Project POCI-01-0145-FEDER-016801 and by FCT under Project PTDC/ AGR-TEC/1140/2014. G Marques acknowledges the European Union's Seventh Framework Program for research, technological development and demonstration under grant agreement no. 613781. M Vosátka was supported by the project NPUI LO1417 of the Ministry of Education, Youth and Sports of the Czech Republic.

\section{References}

Ames RN, Thiagarajan TR, Ahmad MH, McLaughlin WA (1991) Coselection of compatible rhizobia and vesicular-arbuscular mycorrhizal fungi for cowpea in sterilized and non-sterilized soils. Biology and Fertility of Soils 12, 112-116. doi:10.1007/BF00341485

Association of Official Analytical Chemists (2006) 'Official methods of analysis.' 18th edn (Association of Official Analytical Chemists: Gaithersburg, MD, USA)

Augé RM, Kubikova E, Moore JL (2001) Foliar dehydration tolerance of mycorrhizal cowpea, soybean and bush bean. New Phytologist 151, 535-541. doi:10.1046/j.0028-646x.2001.00187.x

Augé RM, Toler HD, Saxton AM (2015) Arbuscular mycorrhizal symbiosis alters stomatal conductance of host plants more under drought than under amply watered conditions: a meta-analysis. Mycorrhiza 25, 13-24. doi:10.1007/s00572-014-0585-4

Bagayoko M, George E, Römheld V, Buerkert A (2000) Effects of mycorrhizae and phosphorus on growth and nutrient uptake of millet, cowpea and sorghum on a West African soil. The Journal of Agricultural Science 135, 399-407. doi:10.1017/S0021859699008254

Baláz M, Vosátka M (2001) A novel inserted membrane technique for studies of mycorrhizal extraradical mycelium. Mycorrhiza 11, 291-296. doi:10.1007/s00572-001-0135-8

Bell LW, Lawrence J, Johnson B, Peoples MB (2017) New ley legumes increase nitrogen fixation and availability and grain crop yields in subtropical cropping systems. Crop \& Pasture Science 68, 11-26. doi:10.1071/CP16248

Brundrett M, Melville L, Peterson RL (1994) 'Practical methods in mycorrhizal research.' (Mycologue Publications: Waterloo, ON, Canada)

Chalk PM, Souza RF, Urquiaga S, Alves BJR, Boddey RM (2006) The role of arbuscular mycorrhiza in legume symbiotic performance. Soil Biology \& Biochemistry 38, 2944-2951. doi:10.1016/j.soilbio.2006.05.005

Diallo AT, Samb PI, Roy-Macauley H (2001) Water status and stomatal behaviour of cowpea, Vigna unguiculata (L.) Walp, plants inoculated with two Glomus species at low soil moisture levels. European Journal of Soil Biology 37, 187-196. doi:10.1016/S1164-5563(01)01081-0

Ehlers JD, Hall AE (1997) Cowpea (Vigna unguiculata L. Walp.). Field Crops Research 53, 187-204. doi:10.1016/S0378-4290(97)00031-2

Elowad HOA, Hall AE (1987) Influences of early and late nitrogen fertilization on yield and nitrogen fixation of cowpea under wellwatered and dry field conditions. Field Crops Research 15, 229-244. doi:10.1016/0378-4290(87)90012-8

FAO (2003) 'Food energy - methods of analysis and conversion factors.' (Food and Agriculture Organization of the United Nations: Rome) Available at: www.fao.org/uploads/media/FAO_2003_Food_Energy_ 02.pdf (accessed 10 February 2017)
FAOSTAT (2017) Statistics Division. Food and Agriculture Organization of the United Nations, Rome. Available at: www.fao.org/faostat/en/\#home (accessed 10 February 2017).

Fery RL (2002) New opportunities in Vigna. In 'Trends in new crops and new uses'. (Eds J Janick, A Whipkey) pp. 424-428. (ASHS Press: Alexandria, VA, USA)

Figueiredo MVB, Burity HA, de França FP (1998) Water deficit stress effects on $\mathrm{N}_{2}$ fixation in cowpea inoculated with different Bradyrhizobium strains. Canadian Journal of Plant Science 78, 577-582. doi:10.4141/ P97-116

Figueiredo MVB, Vilar JJ, Burity HA, de França FP (1999) Alleviation of water stress effects in cowpea by Bradyrhizobium spp. inoculation. Plant and Soil 207, 67-75. doi:10.1023/A:1004403918379

Giovannetti M, Mosse B (1980) An evaluation of techniques for measuring vesicular arbuscular mycorrhizal infection in roots. New Phytologist $\mathbf{8 4}$, 489-500. doi:10.1111/j.1469-8137.1980.tb04556.x

Grewal KS, Buchan GD, Tonkin PJ (1990) Estimation of field capacity and wilting point of some New Zealand soils from their saturation percentages. New Zealand Journal of Crop and Horticultural Science 18, 241-246. doi:10.1080/01140671.1990.10428101

Halilou O, Hamidou F, Taya BK, Mahamane S, Vadez V (2015) Water use, transpiration efficiency and yield in cowpea (Vigna unguiculata) and peanut (Arachis hypogaea) across water regimes. Crop \& Pasture Science 66, 715-728. doi:10.1071/CP14182

Hall AE (2012) Phenotyping cowpeas for adaptation to drought. Frontiers in Physiology 3, 155.

Iqbal MA (2015) Evaluation of forage cowpea and hey as a feed resource for ruminant production: a mini-review. Global Veterinaria 14, 747-751.

Kaschuk G, Leffelaar PA, Giller KE, Alberton O, Hungria M, Kuyper TW (2010) Responses of legumes to rhizobia and arbuscular mycorrhizal fungi: a meta-analysis of potential photosynthate limitation of symbioses. Soil Biology \& Biochemistry 42, 125-127. doi:10.1016/j.soilbio.2009. 10.017

Koide RT, Li M (1989) Appropriate controls for vesicular-arbuscular mycorrhiza research. New Phytologist 111, 35-44. doi:10.1111/j.14698137.1989.tb04215.x

Laguerre G, Nour SM, Macheret V, Sanjuan J, Drouin P, Amarger N (2001) Classification of rhizobia based on $\operatorname{nodC}$ and $n i f H$ gene analysis reveals a close phylogenetic relationship among Phaseolus vulgaris symbionts. Microbiology 147, 981-993. doi:10.1099/00221287-147-4-981

Ngakou A, Tamò M, Parh IA, Nwaga D, Ntonifor NN, Korie S, Nebane CLN (2008) Management of cowpea flower thrips, Megalurothrips sjostedti (Thysanoptera, Thripidae), in Cameroon. Crop Protection 27, 481-488. doi:10.1016/j.cropro.2007.08.002

Nielsen SS, Brandt WE, Singh BB (1993) Genetic variability for nutritional composition and cooking time of improved cowpea lines. Crop Science 33, 469-472. doi:10.2135/cropsci1993.0011183X003300030010x

Oliveira RS, Castro PML, Dodd JC, Vosátka M (2005a) Synergistic effect of Glomus intraradices and Frankia spp. on the growth and stress recovery of Alnus glutinosa in an alkaline anthropogenic sediment. Chemosphere 60, 1462-1470. doi:10.1016/j.chemosphere.2005.01.038

Oliveira RS, Vosátka M, Dodd JC, Castro PML (2005b) Studies on the diversity of arbuscular mycorrhizal fungi and the efficacy of two native isolates in a highly alkaline anthropogenic sediment. Mycorrhiza 16, 23-31. doi:10.1007/s00572-005-0010-0

Oliveira RS, Castro PML, Dodd JC, Vosátka M (2006) Different native arbuscular mycorrhizal fungi influence the coexistence of two plant species in a highly alkaline anthropogenic sediment. Plant and Soil 287, 209-221. doi:10.1007/s11104-006-9067-6

Oliveira RS, Boyer LR, Carvalho MF, Jeffries P, Vosátka M, Castro PML, Dodd JC (2010) Genetic, phenotypic and functional variation within a Glomus geosporum isolate cultivated with or without the stress of a highly alkaline anthropogenic sediment. Applied Soil Ecology 45, 39-48. doi:10.1016/j.apsoil.2010.01.008 
Oliveira RS, Ma Y, Rocha I, Carvalho MF, Vosátka M, Freitas H (2016a) Arbuscular mycorrhizal fungi are an alternative to the application of chemical fertilizer in the production of the medicinal and aromatic plant Coriandrum sativum L. Journal of Toxicology and Environmental Health. Part A. 79, 320-328. doi:10.1080/15287394.2016.1153447

Oliveira RS, Rocha I, Ma Y, Vosátka M, Freitas H (2016b) Seed coating with arbuscular mycorrhizal fungi as an ecotechnological approach for sustainable agricultural production of common wheat (Triticum aestivum L.). Journal of Toxicology and Environmental Health. Part A. 79, 329-337. doi:10.1080/15287394.2016.1153448

Omirou M, Fasoula DA, Ioannides IM (2016) Bradyrhizobium inoculation alters indigenous AMF community assemblages and interacts positively with AMF inoculum to improve cowpea performance. Applied Soil Ecology 108, 381-389. doi:10.1016/j.apsoil.2016.09.018

Ossler JN, Zielinski CA, Heath KD (2015) Tripartite mutualism: facilitation or trade-offs between rhizobial and mycorrhizal symbionts of legume hosts. American Journal of Botany 102, 1332-1341. doi:10.3732/ajb.1500007

Phillips JM, Hayman DS (1970) Improved procedures for clearing and staining parasitic and vesicular-arbuscular mycorrhizal fungi for rapid assessment of infection. Transactions of the British Mycological Society 55, 158-161. doi:10.1016/S0007-1536(70)80110-3

Porter W (1979) The "most probable number" method for enumerating infective propagules of vesicular arbuscular mycorrhizal fungi in soil. Australian Journal of Soil Research 17, 515-519. doi:10.1071/ SR9790515

Rangel A, Saraiva K, Schwengber P, Narciso MS, Domont GB, Ferreira ST, Pedrosa C (2004) Biological evaluation of a protein isolate from cowpea (Vigna unguiculata) seeds. Food Chemistry 87, 491-499. doi:10.1016/ j.foodchem.2003.12.023

Schakel KA, Hall AE (1979) Reversible leaflet movements in relation to drought adaptation of cowpeas, Vigna unguiculata (L.) Walp. Australian Journal of Plant Physiology 6, 265-276. doi:10.1071/PP9790265

Sikora S, Redzepovic S, Bradic M (2002) Genomic fingerprinting of Bradyrhizobium japonicum isolates by RAPD and rep-PCR. Microbiological Research 157, 213-219. doi:10.1078/0944-5013-00153

Singh BB, Ehlers JD, Sharma B, Freire Filho FR (2002) Recent progress in cowpea breeding. In 'Challenges and opportunities for enhancing sustainable cowpea production'. (Eds CA Fatokun, SA Tarawali, BB Singh, PM Kormawa, M Tamo) pp. 22-40. (International Institute of Tropical Agriculture: Ibadan, Nigeria)

Somasegaran P, Hoben HJ (1985) 'Methods in legume-Rhizobium technology.' (Department of Agronomy and Soil Science, University of Hawaii, Hawaii Institute of Tropical Agriculture and Human Resources: Manoa, HI, USA)

Taiwo LB, Osonubi O, Akano MJ (2001) Growth and nodulation of cowpea (Vigna unguiculata) in response to compost and inoculation with Glomus etunicatum and Bradyrhizobium. Tropical Agricultural Research and Extension 4, 101-107.

Timko MP, Singh BB (2008) Cowpea, a multifunctional legume. In 'Genomics of tropical crop plants'. Ch. 10. (Eds PH Moore, R Ming) pp. 227-258. (Springer Science + Business Media LLC: New York)

Weisburg WG, Barns SM, Pelletier DA, Lane DJ (1991) 16S ribosomal DNA amplification for phylogenetic study. Journal of Bacteriology 173, 697-703. doi:10.1128/jb.173.2.697-703.1991

Wellburn AR (1994) The spectral determination of chlorophylls a and b, as well as total carotenoids, using various solvents with spectrophotometers of different resolution. Journal of Plant Physiology 144, 307-313. doi:10.1016/S0176-1617(11)81192-2

Wilson BAL, Ash GJ, Harper JDI (2012) Arbuscular mycorrhizal fungi improve the growth and nodulation of the annual legume messina (Melilotus siculus) under saline and non-saline conditions. Crop \& Pasture Science 63, 164-178. doi:10.1071/CP11193

Zhang YF, Wang ET, Tian CF, Wang FQ, Han LL, Chen WF, Chen WX (2008) Bradyrhizobium elkanii, Bradyrhizobium yuanmingense and Bradyrhizobium japonicum are the main rhizobia associated with Vigna unguiculata and Vigna radiata in the subtropical region of China. FEMS Microbiology Letters 285, 146-154. doi:10.1111/j.15746968.2008.01169.x 